\title{
MODALITY AND MODAL VERBS IN THE CONSTITUTION OF THE REPUBLIC OF KOSOVO
}

\author{
Fatbardha Hoxha \\ University “Isa Boletini” in Mitrovicë, Kosovë \\ fatbardha.hoxha@umib.net
}

\begin{abstract}
This article on the topic of modality and modal verbs, more specifically its main aim is to identify and classify modal verbs that express deontic modality in the Albanian language, bringing an overview of modal expressions used in the legal register, specifically in the Constitution of the Republic of Kosovo. Modal verbs are a key component of the legal language consequently the current analysis focuses on the appearance of modals as well as how often they are used in legal documents. The theoretical part focuses on the types of modality and the meaning of modal verbs. To that end, the articles analyses the modality and modal verbs found in the Constitution of the Republic of Kosovo. Using corpus analysis methods, the article reveals the most commonly used modality in this legislative text.
\end{abstract}

Keywords: modality, modal verbs, mund, duhet, do.

\section{Introduction}

\subsection{Modality and its types}

Modality can be defined as the way in which the meaning of a clause is classified in such a way as to reflect the speaker's judgment of the likelihood that the proposition, he expresses is true (Quirk et al 1989: 219). In practical terms, the term modality includes various semantic notions such as ability, possibility, obligation, and imperative meaning (Huddleston 2002, 173).

Two main types of modality are generally known, epistemic modality and deontic modality. However, different linguists use different terminology for these two types of modality. Von Wright (1951) classifies modality into aleticlogical mode, epistemic mode, deontic mode, and existential mode. Lyons (1977) categorizes modality into instrumental, epistemic, and deontic modalities. Coates (1983) categorizes modality as radical and epistemic. Halliday and Matthiessen (2008) classify modality as modalization and modulation: the first expresses probability and pattern and the second shows coercion and tendency. Palmer's (1979) modality includes epistemic modality, deontic modality, and dynamic modality, although in 1986 Palmer added evidence-based modality to his classification as well. He has made a division of these types of modality into two groups: the propositional modality and the event modality. Epistemic and evidentiary systems are the two main types of propositional modality. According to him, the epistemic modality and the evidential (evidential) modality have to do with the speaker's attitude towards the value of the truth or the factual status of the proposal (prepositional modality). Meanwhile, deontic and dynamic modality refer to events that have not been actualized, events that have not occurred, but are simply possible (event modality) (Palmer, 2001: $8)$.

The difference between epistemic modality and apparent modality is that with epistemic modality the speakers express their judgments about the factual status of the proposal, while with deductive modality the speakers provide evidence for its factual status (Palmer, 2001: 9). The difference between deontic and dynamic modality is that in the case of deontic modality the conditioning factors are external to the individual concerned, whereas with dynamic modality they are internal (Palmer, 2001: 9-10).

Since the deontic modality derives from an external authority, such as rules or law, then this paper will focus on this type of modality.

In the Albanian language, modality has not been thoroughly studied. In the AKSHSH grammar, modals are briefly addressed within the verbal system and are generally described as modal value verbs (ASH 2002: 261). The first 
researcher who researched different areas of modality that express the analytical grammatical forms of verbs was the Albanologist Selman Riza (1997). According to him, the verbs I want, can and should in their lexical form express psychological and moral concepts, such as: the concept of necessity, possibility, will, obligation and permission. Data analyzed in Albanian by Sejdiu Rugova \& Zogaj (2015) find that Albanian Language complements the system proposed by Palmer (2001), who claims that the epistemic modality is expressed through three types of judgments that are common in language: speculative (by expressed uncertainty), deductive (indicating a conclusion from observable evidence) and hypothetical (indicating the conclusion from what is already known), and that the markers for this system are the verbs: mund, duhet, do.

\subsection{Deontic modality}

Deontic (or internal) modality refers to actions and events that people (or other factors) directly control: meanings related to permission, obligation, or will (Biber et al., 2000: 485). These meanings refer to the authority and judgment of the speaker rather than knowledge or belief. Punishments with deontic meanings are often used to influence the execution of actions or situations (Huddleston 2002, 54).

According to Palmer, with deontic modality the conditioning factors are external to the individual concerned, consequently the deontic modality is related to the obligation or permission, deriving from an external source:

\section{i. John can enter now (permission)

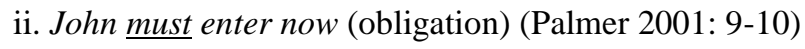

Legal texts display a variety of modal meanings, such as coercion, prohibition, recommendation, advice, authorization, and so on. Models (mund, duhet, do) are a major part of legal texts. For example, the participle do + the conjunction of the verb in spoken and written language represent the future tense and is not so common in use, while in legal texts it represents a modal form, which implies necessity and is an active figure of these texts.

In the Albanian language, modality is expressed with modal verbs, such as: should, can and will, with lexical verbs in a semi-modal function: let, allow, do, know and dare (the last two borrowings from Serbian into Kosovo Albanian mainly), with verb moods (desire, surprise and the subjunction with non-factual meaning, with lexical means, such as modal adverbs: maybe, definitely, surely, etc., which mainly express epistemic modality, with modal adjectives (safe, doubtful, forced etc.) (Rugova, Sejdiu Rugova 2015: 178-179).

The practical part of the paper deals with the analysis of modal verbs used in the Constitution of the Republic of Kosovo. The main focus of the practical part is on modal verbs. The first part will present the general frequency of modals mund, duhet, do, while the use and meaning of modal verbs are analyzed more closely below. They are analyzed based on the three meanings they express: obligation, prohibition and permission.

\section{Analysis of Findings}

This analysis focuses on the Constitution of the Republic of Kosovo, adopted on 15.6.2008, which has 162 articles and a total of 72 pages. The text is analyzed to find the modal verbs mund, duhet, do. There are a total of 271 modal verbs in this document. The graph below shows the total frequency of the modules mund, duhet, do in the analyzed text. 


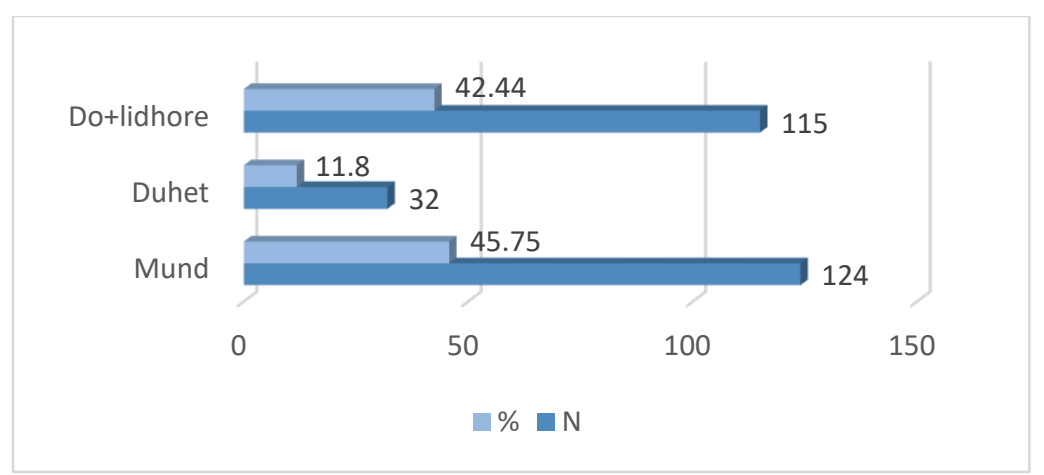

Graph 1. Frequency of modals in the Constitution of the Republic of Kosovo

As it is evident from the figure above, the most used module in our corpus is the modal can, the second modality in terms of frequency was do + subjunction, while the module duhet was the least used, it was used 32 times in total or $11.8 \%$, and of this only one time in a negative form. To summarize the results of this comparison, the frequent use of the modality mund + subjunction should be noted. The frequent use becomes even more important as it is the most obvious marker of the deontic modality in the legal language, followed by the do + subjunctive particle, which in the legal language express permission and obligation. Based on the results we can assume that duhet is used more often to express obligations in conversation than in legal language.

\subsection{Deontik permission}

The deontic permission in the analyzed text is expressed by the verb can, which expresses the modal meaning of possibility or permission when followed by another verb in the connective mode. The following examples show the use of the modal can, which followed by the conjunction of the verb is interpreted as an expression of permission:

(1) Liria e manifestimit të fesë, e besimit dhe e ndërgjegjes mund të kufizohet me ligj, nëse një gjë e tillë është e domosdoshme për mbrojtjen e sigurisë dhe rendit publik, të shëndetit, ose të të drejtave të personave të tjerë.

(1) Freedom of expression of religion, belief and conscience may be restricted by law if it is necessary for the protection of the security and public order, of health, or of the rights of other persons.

(2) Mandati i Kuvendit të Kosovës mund të vazhdohet vetëm në raste të Gjendjes së Jashtëzakonshme për masa emergjente të mbrojtjes ose në rast të rrezikut ndaj rendit kushtetues ose sigurisë publike të Republikës së Kosovës, dhe vetëm për aq sa zgjat Gjendja e Jashtëzakonshme, siç është përcaktuar me këtë Kushtetutë.

(2) The mandate of the Assembly of Kosovo may be extended only in cases of State of Emergency for emergency protection measures or in case of danger to the constitutional order or public security of the Republic of Kosovo, and only for as long as the State of Emergency lasts, such as is defined by this Constitution.

(3) Secili shtetas i Republikës së Kosovës i cili është tetëmbëdhjetë (18) vjeç ose më i madh dhe përmbush kriteret ligjore, mund të jetë kandidat për deputet.

(3) Any citizen of the Republic of Kosovo who is eighteen (18) years of age or older and meets the legal criteria, may be a candidate for deputy.

The expression of prohibition through the verb can is made when the negative particle not or s are placed before it:

(4) Ashpërsia e dënimit nuk mund të jetë në disproporcion me veprën penale.

(4) The severity of the sentence may not be disproportionate to the criminal offense.

In our analysis, with the value of not + can the negative part nor was also used in order to avoid verb repetition:

(5) Nuk mund të kandidohen dhe as të zgjidhen deputetë të Kuvendit, pa hequr dorë paraprakisht nga detyra e tyre. 
ISSN 2661-2666 (Online) International Scientific Journal Monte (ISJM) DOI: 10.33807/monte.20211839

Volume 4, (No).1 (2021): April

(5) Members of the Assembly may not be nominated nor elected without resigning from office in advance.

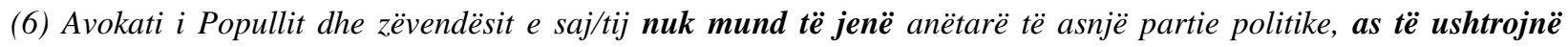
veprimtari politike, shtetërore a private profesionale dhe as të marrin pjesë në organizmat drejtues të organizatave civile, ekonomike dhe tregtare.

(6) The People's Advocate and his / her deputies may not be members of any political party, nor exercise political, state or private professional activities, nor participate in the governing bodies of civil, economic and commercial organizations.

Evidently, the particle nor is a substitute in the cohesive plane, which is put in place of the unit can not. In fact this can be seen as a unit that precedes nor (can not). Therefore, it separately expresses the prohibition mode.

\subsection{Deontic obligation}

The deontic obligation in the analyzed text is expressed with the verbs duhet and do, accompanied by the verb in the subjunctive.

\section{i. Modal verb do+subjunctive particle}

Do followed by the subjunction in the Albanian language is used to refer to the future tense, either in the sense of will or prediction. However, in legal language this verbal form is used to express obligation and is among the most common forms and can be found in all types of legal documents. The reason for its excessive use is that legal drafters, but also lawyers, use it for many other purposes, because of its flexibility, because it can mark a variety of meanings. According to Butt (2006: 131), the purposes of the modal verb do + subjunction ("shall" in English) in legal language are: to assign an obligation/duty, to give right, to give direction, in state circumstances, to create a precedent, create a condition and express the future.

(7) Të gjitha interesat në pronësi shoqërore në prona dhe ndërmarrje në Kosovë do të jenë në pronësi të Republikës së Kosovës.

(7) All socially owned interests in property and enterprises in Kosovo shall be owned by the Republic of Kosovo.

(8) Gjatë Gjendjes së Jashtëzakonshme, Këshilli i Sigurisë i Republikës së Kosovës do të bashkëpunojë ngushtësisht me Qeverinë, Kuvendin dhe autoritetet ndërkombëtare.

(8) During the State of Emergency, the Security Council of the Republic of Kosovo shall cooperate closely with the Government, the Assembly and the international authorities.

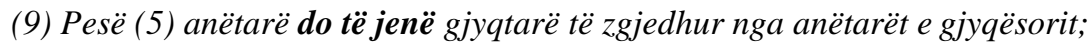

(9) Five (5) members shall be judges elected by the members of the judiciary;

Similarly, in this verbal form the prohibition is expressed by placing the negative particle not or s' in front of the modal $d o$. So the main function of the negative form of $d o+$ subjunction is to express prohibition:

(10) Tre (3) gjyqtarët nuk do të jenë qytetarë të Kosovës dhe as të ndonjë vendi fqinj.

(10) Three (3) judges shall not be citizens of Kosovo or any neighboring country.

(11) Dispozitat e nenit 70.3.(3) nuk do të aplikohen deri në seancën konstituive të Kuvendit pas zgjedhjeve të para parlamentare pas hyrjes në fuqi të kësaj Kushtetute.

(11) The provisions of Article 70.3 (3) shall not apply until the constitutive session of the Assembly after the first parliamentary elections following the entry into force of this Constitution.

(12) Republika e Kosovës nuk ka pretendime territoriale ndaj asnjë shteti ose pjese të ndonjë shteti dhe nuk do të kërkojë të bashkohet me asnjë shtet ose pjesë të ndonjë shteti.

(12) The Republic of Kosovo has no territorial claims against any state or part of any state and shall not seek to join any state or part of any state. 
In addition, the particle nor, as a substitution in the cohesive plane, in example (10) is placed instead of the unit will not be and expresses prohibition.

\section{ii. Modal verb duhet}

According to Albanian grammar researchers (ASHSH, 2002), the semi-auxiliary verb duhet expresses the modal meaning of obligation or necessity. It can be followed by the subjunctive mode or by the participle. When followed by the past participle of the conjunction, the verb duhet expresses a stronger assumption. When it is not followed by another verb in the connective or partial way, but by a noun or pronoun that serves as its subject, the verb duhet does not have a modal meaning, but is used as a verb with full lexical meaning (ASHSH, 2002: 263). The modal value of the verb $s$ duhet in the Albanian language is expressed when it is followed by another verb in the subjunctive or participle, with which it expresses the modal meaning of obligation or necessity.

(13) Me kërkesën e Kuvendit, Avokati i Popullit duhet të dorëzojë raporte periodike ose tjera Kuvendit. Me kërkesën e Avokatit të Popullit, Kuvendi duhet t’ia lejojë që tëdëgjohet.

(13) At the request of the Assembly, the People's Advocate shall submit periodic or other reports to the Assembly. At the request of the People's Advocate, the Assembly must allow him to be heard.

(14) Nëse as herën e dytë nuk zgjidhet Qeveria, atëherë Presidenti i Kosovës i shpall zgjedhjet, të cilat duhet të mbahen jo më vonë se dyzet (40) ditë nga dita e shpalljes së tyre.

(14) If the Government is not elected for the second time, then the President of Kosovo announces the elections, which must be held no later than forty (40) days from the day of their announcement.

Prohibition through the form duhet + subjunction is expressed as in the other modalities mentioned above, specifically through the use of negative particle not or s'. In the text analyzed this form of prohibition was found in only one case:

(15) Parimet e tjera për veprimet e institucioneve publike gjatë Gjendjes së Jashtëzakonshme rregullohen me ligj, por ato nuk duhet të jenë në shpërputhje me këtë nen.

(15) Other principles for the actions of public institutions during the State of Emergency are regulated by law, but they should not be inconsistent with this article.

In the text analyzed, the modal duhet was used less frequently, appearing only 31 times in its affirmative form and 1 time in the negative.

\section{Conclusion}

The purpose of this paper was to analyze the modalities used in legal texts. In the theoretical part the terms modality, epistemic modality and deontic modality were introduced, which are fundamental to understanding the research in the practical part. Since the main function of legal language is to determine rights, express allowance/permit, and impose obligations, the rest of the analysis dealt with the deontic modality. This function of legal language in the analyzed text was expressed through the modalities mund, duhet and $d o$, with the meaning of permission and obligation.

Based on our findings, the most used modal in the text was the can modal, which followed by the verb in the subjunctive was interpreted as the expression of permission. The second model in terms of frequency was do+ which in the analyzed text was used to indicate rights or oblications. In order to express the obligation or the necessity the modal duhet was least used.

To summarize the results of this analysis, reveal the frequent use of the do+ subjunctive particle, which is the most obvious marker of the deontic modality in the legal language, followed by the do + subjunctive particle, which in the legal language expresses permission and obligation.

The expression of prohibition was introduced through the verbs mund, duhet and $d o$, preceded by the negative particle not. In addition, the negative particle nor is also used, as a substitution for the not+can form. In fact, this can be seen as a unit that precedes the particle nor (can not), therefore it expresses prohibition. 


\section{References}

ASHSH: Çeliku M., Domi M., Floqi S., Mansaku S., Përnaska R., Prifti,S. and To-toni M., 2002, Gramatika e gjuhës shqipe - Morfologjia, 1st ed. Tiranë: Akade-mia e Shkencave.

Biber, D. et al. (2000): Longman Grammar of Spoken \& Written English. London: Longman.

Butt, Peter J. 2006. Modern Legal Drafting: A Guide to Using Clearer Language. $2^{\text {nd }}$ ed.Cambridge: Cambridge University Press.

Coates, J. (1983), The semantics of the modal auxiliaries, Croom Helm.

Halliday, M. A. K., \& Matthiessen, C. M. I. M. (2008), An introduction to functional grammar. Foreign Language Teaching and Research Press, Beijing.

Huddleston, Rodney, and Geoffrey K. Pullum. 2002, A Students Introduction to English Grammar. Cambridge, U.K.: Cambridge University Press

Huddleston, Rodney, and Geoffrey K. Pullum. 2002, The Cambridge Grammar of the English Language. Cambridge, U.K.: Cambridge University Press.

Linditë Sejdiu L. dhe Zogaj D. (2017). Epistemic modality expressed through modal verbs in Albanian. Linguistica copernicana nr. 14 / 2017

Lyons, J. (1977), Semantics, Cambridge University Press.

Palmer F., 1979, Modality and the English modals, London: Longman.

Palmer F., 1986, Mood and modality, Cambridge: Cambridge University Press.

Palmer F., 2001, Modality, 1st ed. Cambridge: Cambridge University Press.

Quirk, Randolph, Sidney Greenbaum, Geoffrey Leech, and Jan Svartvik. 1989, A Comprehensive Grammar of the English Language, Harlow: Longman

Riza S., 1997, Vepra 2, Prishtinë: Akademia e Shkencave dhe e Arteve e Kosovës.

Rugova B, Sejdiu L. (2015), Hyrje në gramatikën e tekstit të gjuhës shqipe. Tremebelat. Prishtinë

Šarčević, S. (1997), New approach to legal translation, The Hague: Kluëer Laë International.

Topalli K., 2010, Sistemi foljor i gjuhës shqipe, Tiranë: Plejad.

Von Wright, G. H. (1951), An essay in modal logic, North-Holland Publishing Company, Amsterdam. 